\title{
Karlsruhe über alles? The reasoning on the principle of proportionality in the judgment of 5 May 2020 of the German BVerfG and its consequences()
}

\author{
di Diana-Urania Galetta \\ Full Professor of Administrative Law \\ University of Milan
}

The judgment of 5 May 2020 of the Zweiter Senat of the Bundesverfassungsgericht, to the extent that it expresses the German constitutional judge's claim to assess the legality of the ECB's decisions on the basis of the principles of attribution and proportionality, is more than questionable in point of law. Furthermore, it is extremely dangerous: and not only because it implies that the Zweiter Senat ultimately refuses, on the basis of the democratic principle and the control of the Union's competences, the uniformity of application of EU law. But also because it appears as the glaring demonstration of a form of "cultural bullying" many complain about, and which emerges in a crystal clear way in the reasoning carried out on proportionality. This is an attitude which, in the contingency caused by the COVID-19 emergency, could have truly tragic consequences for the future of the European Union.

La sentenza 5 maggio 2020 del Zweiter Senat del Bundesverfassungsgericht, nella misura in cui esprime la pretesa del giudice costituzionale tedesco di valutare la legalità delle decisioni della BCE sulla base dei principi di attribuzione e di proporzionalità è più che discutibile in punto di diritto. Inoltre essa è estremamente pericolosa: e non solo perché implica che il Zweiter Senat, in ultima analisi, rifiuta, sulla base del principio democratico e del controllo delle competenze dell'Unione, l'uniformità di applicazione del diritto dell'Unione. Ma anche perché essa appare come la lampante dimostrazione di una forma di "bullismo culturale" lamentato ormai da più parti; e che emerge in maniera lampante nel ragionamento svolto sulla proporzionalità. È un atteggiamento questo che, nella contingenza causata dall'emergenza COVID-19,

(1) This is the English translation, made by the author herself, of the article already published on May 7, 2020, in https://www.federalismi.it/. Its only purpose is to make the paper accessible to a wider audience. For this reason, the paper has not undergone a linguistic revision, and also the syntax is more or less the same as in the Italian (original) version. See Italian (original) version at: https://www.federalismi.it/nv14/articolodocumento.cfm?hpsez $=$ Primo_Piano\&content $=$ Karlsruhe $\% 2 \mathrm{~B} \% \mathrm{C} 3 \% \mathrm{BCber} \% 2 \mathrm{~B}$ alles $\% 3 \mathrm{~F} \% 2 \mathrm{BIl} \% 2 \mathrm{Bragionament}$ O $\% 2 \mathrm{Bsul} \% 2 \mathrm{Bprincipio} \% 2 \mathrm{Bdi} \% 2 \mathrm{Bp}$ roporzionalit $\% \mathrm{C} 3 \% \mathrm{~A} 0 \% 2 \mathrm{Bnella} \% 2 \mathrm{~B}$ pronunzia $\% 2 \mathrm{Bdel} \% 2 \mathrm{~B} 5 \% 2 \mathrm{Bmaggio} \% 2 \mathrm{~B}$ $2020 \% 2 \mathrm{Bdel} \% 2 \mathrm{BBVerfG} \% 2 \mathrm{Btedesco} \% 2 \mathrm{Be} \% 2 \mathrm{Ble} \% 2 \mathrm{Bsue} \% 2 \mathrm{~B}$ conseguenze\&content_auth $=\% 3 \mathrm{Cb} \% 3 \mathrm{EDiana} \% 2$ DUrania $\% 2 B G$ aletta $\% 3 \mathrm{C} \% 2 \mathrm{Fb} \% 3 \mathrm{E} \&$ Artid $=42380$. 
potrebbe avere conseguenze davvero tragiche per il futuro dell'Unione.

Sommario: 1. The decision of the Zweiter Senat. 2. The principle of proportionality: Verbältnismäßigkeitsgrundsatz or EU principle of proportionality? 3. Law as a social science? Attempts at "cultural hegemony" and unforgivable mistakes.

\section{The decision of the Zweiter Senat}

The judgment of the Zweiter Senat of the Bundesverfassungsgericht (BVerfG) of May 5, 2020 ${ }^{2}$ is the final ruling on the constitutional complaints of a number of natural persons, including the now well-known Gauweiler, who, among others, was at the origin of the $B V \operatorname{erf} G$ 's first reference for a preliminary ruling to the EU Court of Justice. This had happened - as is now also well known - in the context of various constitutional complaints requesting the $B V \operatorname{erf} G$ to prevent, by means of an injunction, the ratification by Germany of the Treaty establishing the European Stability Mechanism (ESM) ${ }^{3}$.

In the present case, with various constitutional complaints ${ }^{4}$ which were brought together, the $B V \operatorname{erf} G$ was requested to declare illegitimate the decisions of the European Central Bank (ECB) which establish and implement, from 2015, the Public Sector Purchase Programme (PSPP) on the purchase of government bonds on secondary markets.

On this point, the applicants' complaints were rejected. The $B V \operatorname{erf} G$ admitted that it is not the judge of the legitimacy of the acts of the EU institutions, bodies, offices and agencies.

However, the BVerfG was also asked to condemn the Bundestag (Federal Parliament) and the Federal Government, as well as the Federal Central Bank (Bundesbank) for failing to take all necessary measures to prevent the Governing Council of the European Central Bank (ECB) from taking the decisions in question. The complainants were also seeking an injunction obliging the German federal institutions to take all necessary measures to counteract the action of the ECB. Those applications were only partially admitted $^{5}$. Finally, the applicants requested the $B V \operatorname{erf} G$ to issue an injunction to the Bundesbank to refrain from purchasing securities on the secondary markets under the PPSP. The latter request was fully granted and the BverfG therefore prohibited the Bundesbank as an institution of the Federal Republic of Germany

\footnotetext{
2 BVerfG, Judgment of the Second Senate of 05 May 2020 - 2 BvR 859/15 -, paras. (1-237), http://www.bverfg.de/e/rs20200505 2bvr085915en.html.

3 Judgment of the Court (Grand Chamber) of 16 June 2015, in Case C-62/14, Peter Gauweiler and Others v Deutscher Bundestag, ECLI:EU:C:2015:400.

${ }_{4}^{4}$ The proceedings 2 BvR 859/15, 2 BvR 1651/15, 2 BvR 2006/15 and 2 BvR 980/16 were combined for joint decision.

${ }^{5}$ For a more detailed analysis see J. Ziller, The unbearable heaviness of the German constitutional judge. On the judgment of the Second Chamber of the German Federal Constitutional Court of 5 May 2020 concerning the European Central Bank's PSPP programme, in CERIDAP, 2/2020, https://ceridap.eu/the-unbearable-heaviness-of-the-german-constitutional-judgeon-the-judgment-of-the-second-chamber-of-the-german-federal-constitutional-court-of-5-may-2020-concerningthe-european-central-banks-pspp/.
} 
from making such purchases if the ECB did not convincingly demonstrate within three months that the challenged decisions complied with the principle of proportionality ${ }^{6}$. But not, with the principle of proportionality as a general principle of EU law, as it has been shaped and adapted in its abundant caselaw by the EU Courts, but rather the German "Verbältnismäßigkeitsgrundsatz"!

\section{The principle of proportionality: Verbältnismäßigkeitsgrundsatz or EU principle of proportionality? The misunderstanding of the Court of Karlsruhe}

The principle of proportionality, to which I have devoted so much "scientific effort" in my academic life 7 , certainly takes the lion's share in this ruling. Suffice it to say that the term verbältnismäßig/ unverbältnismäßig is used 67 times in the text of the Karlsruhe judges' decision.

On the substance, however, it is an attempt (clumsy and ill-concealed!) to lecture the Court of Justice of the European Union on what the principle of proportionality is and how it should be applied.

A few brief remarks in this regard, at first reading, is therefore a must.

First of all, the lesson is given, albeit from the benches of the Zweiter Senat, referring to primarily AngloAmerican writings of legal scholars. This shows, on the one hand, that not even the German judges of the Zweiter Senat are immune from the recent "English-speaking-mania" that leads many scholars to cite literature mainly in English, even when this is not at all relevant. Of course, this remark is not intended to suggest that the Anglo-American academic literature quoted in the text of this judgment is "not at all" relevant. What is striking, however, is how the reference to this academic literature is to the detriment of the reference to well-known scholars of German public law who wrote fundamental pages on the subject (Fritz Fleiner, but also Ruppert von Krauss, Klaus Stern: and the list would still be long!) ${ }^{8}$. In an attempt, perhaps, to conceal that attitude of "cultural dominance" which clearly transpires (at least in my eyes) from all the reasoning of the Zweiter Senat regarding the principle of proportionality, and the necessity that the decisions taken within the PSPP programme respect it.

However (and for this reason this is a clumsy attempt), when the Zweiter Senat of the German Federal Constitutional Court applies its own national reasoning scheme to the application of the principle of proportionality by the EU Court of Justice, it is making a mistake that seems to me frankly unforgivable. It forgets as a matter of fact that, although the EU Court of Justice has certainly been inspired by the

\footnotetext{
${ }^{6} \int 235$ of the BVerfG judgment.

7 S. the last one published: D.U. Galetta, Il principio di proporzionalità fra diritto nazionale e diritto europeo (e con uno sguardo anche al di là dei confini dell'Unione Europea), in Rivista italiana di diritto pubblico comunitario, 2019/6, p. 903 ss.

${ }^{8}$ In fact, only the 1961 book by P. Lerche is recalled: P. Lerche, Übermaß und Verfassungsrecht. Zur Bindung des Gesetzgebers an die Grundsätze der Verbälnismäßigkeit und der Erforderlicbkeit, which, however, is only one of the many „German classics" on the subject. For a non-exclusive list of this scholarly contributions see in the footnotes of my latest paper on the subject, cit. in note nr. 6.
} 
German model of judicial review of the principle of proportionality ${ }^{9}$, one thing is to point out that this has happened in practice ${ }^{10}$. Another thing is to infer (as the Zweiter Senat does here) that this implies kind of a "guardian role" on the part of the German Federal Constitutional Court on the way in which the EU Court of Justice applies this principle in its own case-law!

That's not all yet! In acting as a censor of the way in which the EU Court of Justice has applied the principle of proportionality in its case-law up to now, the Zweiter Senat seems to ignore the fact - which I have repeatedly pointed out, even recently ${ }^{11}$ - that the Court of Justice also has a style of drafting rulings, that is totally different from the German Federal Constitutional Court's one. Starting with the detail (which it is not a detail, of course!), that the EU Court of Justice is not allowed to refer to the writings of legal scholars in the text of its judgments, in support of the conclusions reached: as the German constitutional judge does, in abundance.

The more concise style of the judgments of the Court of Justice, together with the fact that it is not allowed to refer to the writings of legal scholars, can (and here, it certainly does) give rise to an easy misunderstanding: that the judgments on the proportionality of the Bundeverfassungsgericht are by definition 'better', because they are more widely argumented and supported by such references (to legal scholars).

However, one has to bear in mind - and perhaps it was never as important as it is today! - that the European Union, and the EU Court of Justice (which is one of its main Institutions), are the result of a mediation between different national traditions: those of the (now 27) Member States, which have each brought something within the EU and its Institutions, thus avoiding the dominance of one (legal) culture over the others. And this is also true, of course, with regard to the aspect (largely linked to the specific national tradition) relating to how judgments are drafted. This it is even more true - and a fortiori true - with regard to the content of those general principles of law which, if they are often born in the bedrock of national traditions from which they are "borrowed" from the EU Judges of Luxembourg, once they have entered the jurisprudence of the EU Court, they necessarily acquire autonomy with respect to the systems of origin and become, precisely, "general principles of EU Law", as such autonomous and "other" with respect to those of the (national) system of origin ${ }^{12}$.

However, it seems clear to me that it is mostly the difference between the German and the EU judges in writing style - and in the way of drafting their own judgements - that plays a role in this context. I mean that in the rulings on proportionality drafted by the EU Court of Justice (and which the Zweiter Senat abundantly recalls in its judgment ${ }^{13}$ ) only the essential passages of legal reasoning often emerge. That's

\footnotetext{
${ }^{9}$ And which I myself advocated on various occasions, in different papers on the subject.

${ }^{10} \mathrm{As}$ I myself did, on several occasions, in various writings on the subject.

${ }^{11}$ See also in D.U. Galetta, Il principio di proporzionalità fra diritto nazionale e diritto europeo cit.

12 See further in D.U. Galetta, Le fonti (del diritto amministrativo europeo), in S. Battini, E. Chiti, D.U. Galetta, B.G. Mattarella, C. Franchini, G. della Cananea, Diritto amministrativo europeo, Milan, 2^ edition, 2018, p. 103 ss. ${ }^{13} \$ 126$ of the BVerfG judgment.
} 
why also the prognostic analysis (and the prognostic evaluation) often do not emerge very clearly in its case-law.

This is also due to the fact that the recapitulation of the factual and legal background already takes a great deal of space in the context of the EUCJ rulings. This is precisely because it is a court that must necessarily interact with different national legal systems, which, from time to time, must be properly combined/intersected with the relevant EU law rules.

For the same reason, it may sometimes appear that the proportionality test carried out by the EUCJ is carried out by altering the sequence of application of its constituent elements. Whereas, on the other hand, it is often only the concise way in which the EU Court of Justice's legal reasoning is presented that leads legal scholars to sometimes raise doubts about the existence of logical leaps in the Court's reasoning.

Of all which the Zweiter Senat seems not to be at all aware of, as it criticises the case-law of the Court of Luxembourg (and not in a concealed way) for the fact that the latter does not seem to exactly retrace the pattern of reasoning of the principle of proportionality as it is applied (but the use of the conditional form would be necessary here! ${ }^{14}$ ) by the German constitutional judge in its case-law ${ }^{15}$. Moreover, forgetting that, when the EU judge applies the principle of proportionality, it often does so in his capacity as administrative judge and not as the judge of laws!

As a consequence, I am not at all sure that the final criticism/remark on the CJEU's way of applying the principle of proportionality hits the spot, either. I refer to the critical remark (in $\int 127$ of the judgement) to the way in which the EU Court of Justice has applied the principle of proportionality in its case-law and which would render the the principle of proportionality meaningless and precisely 'devoid of function' (ungeeignet beziehungsweise funktionslos). The way in which the EU Court of Justice has applied the principle of proportionality in its case-law, in order to delimit the boundaries between monetary policy (which an exclusive competence of the European Union), on the one hand, and economic policy, on the other hand.

The truth is that this is simply a different way (the EU Court of Justice's own way!) of applying and, above all, of stating reasons for its decisions on the application of the principle of proportionality. And this diversity seems all the more acceptable the greater is the emphasis the Zweiter Senat places on the aspect of due respect for the Constitutional identity (German Constitutional identity), Verfassungsidentität): a term

\footnotetext{
${ }^{14}$ In fact, the BVerfG ruling starts from a premise, which does not correspond to the reality of the facts: namely, that there is a consensus among German judges (and German scholars) as to how (and with what depth in the analysis of each of its three steps' test) the principle of proportionality should be applied. In this respect, s. e.g. W. LEISNER, Der Abwägungsstaat: Verbältnismäßigkeit als Gerecbtigkeit, Berlin, 1997; M. ALBERS, Gleichbeit und Verbältnismäßigkeit, in Juristische Schulung, 2008/11, p. 945 ss.

${ }^{15}$ I refer to the passage in $\ 126$ where it is clearly stated (and this is not a positive appreciation!) that "In der Rechtsprechung des Gerichtshofs kennzeichnen die Begriffe „geeignet“, „erforderlich“ oder „notwendig“ oftmals die Anwendung des Grundsatzes, ohne dass damit eine vollständige Übereinstimmung mit der deutschen Terminologie und Dogmatik verbunden wäre"
} 
that is used 15 times in the text of the judgment. As well as on the related aspect of defence against the erosion of national competences by the European Union (Erosion mitgliedstaatlicher Zuständigkeiten) ${ }^{16}$.

In conclusion - and in response to the lesson that the Zweiter Senat here seeks to impart to the Luxembourg Court (on the principle of proportionality and on how it should be applied) - it should be emphasized that, if the protection of national identity and national competences ${ }^{17}$ is really as important as the ruling of the Zweiter Senat seems to imply, so is the defence of the European Union (and of its Supreme Court) and of the autonomy of its own legal order against all the attempts by national courts to state their (cultural) supremacy. No matter which Court tries to do that!

\section{Law as a social science? Attempts at "cultural hegemony" and unforgivable mistakes}

The judgment of the Zweiter Senat of the German Bundesverfassungsgericht hits like a tzunami on the European Union, already put to the test by the health emergency caused by the COVID-19 and the economic crisis of immense proportions (although not yet fully quantifiable) that it will almost certainly leave us a tragic legacy ${ }^{18}$.

Apart from the specific contents of the judgement itself - and from the legal errors that it undoubtedly contains from the EU Law point of view ${ }^{19}$ - what is striking about this decision is, first of all, the poor timing of the judgement. The judgment - allow me the strong vis polemic - seems to have been issued by a group of judges ${ }^{20}$ who live on Mars; and who have completely forgotten the characteristic of "social science" of law. As a social science it has one characteristic in common with the other social sciences: to be all "born on the basis of a conscious effort of knowledge of society or, better, of human societies" 21 . The Zweiter Senat seems not only to have not taken the slightest interest in this aspect of the issue. Worse still, the words used by its outgoing President (sigh!) Andreas Voßkuble, as reported in the Frankfurter Allgemeine, reveal a very poor awareness of what it implies, in the terrible contingency in which we find ourselves today, the fact that law is a social science ${ }^{22}$.

\footnotetext{
16 \$156 ss. of the BVerfG judgment.

17 The concept used is "kontinuierliche Erosion mitgliedstaatlicher Zuständigkeiten" ( $(156$ and Leitsatz nr. 4).

18 On this point, please refer to the editorial by R. Leoncini, Verso il post emergenza Covid-19: Business as usual o nuove opportunita??, in Federalismi.it, n. 12/2020, p. 1 ss.

${ }^{19}$ See again J. Ziller, The unbearable heaviness of the German constitutional judge cit., who underlines that "Their entire reasoning is based on the distinction between monetary policy - an exclusive competence of the Union - and economic policy, a competence of the Member States. One wonders whether the judges have understood that the competence in the field of economic policy, although not included among the shared competences listed in Article 4 TFEU, is also a competence of the Union since, as Article 6 TFEU reminds us, the Council - Institution of the Union - is empowered to adopt measures useful for the cooperation of the economic policies of the Member States".

${ }^{20}$ There is a dissenting opinion which, however, to date (7th May 2020) has not been published (and may be it never will!).

${ }^{21}$ Chapter of P. Rossi, Social Sciences, in Enciclopedia delle scienze sociali, 1997.

22 R. Müller, Die Amtszeit von Andreas Voßkuble endet in Kürze: Durch das Grundsatzurteil zum EZB-Anleihenkaufprogramm beendet der Präsident des Bundesverfassungsgerichts seine Amtszeit genauso spektakulär wie er sie begann, in Frankfurter Allgemeine,
} 
So, if the claim by the judges of the Zweiter Senat to assess the legality of ECB decisions on the basis of the principles of attribution and proportionality is - as it has already been underlined by a distinguished scholar - more than questionable in law, it is, above all, extremely dangerous. Not only because it implies "its rejection of the unity of application of Union law on the basis of the democratic principle and the review of the distribution of competences between the Union and the Member States" ${ }^{23}$. But also because it appears as the blatant demonstration of a form of "cultural bullying" many complain about, and which is only one of a thousand facets of the unbearable arrogance which is characterising, more generally, the approach of some Member States in the management of the economic emergency linked to the COVID19 pandemic. This attitude could, alas, have tragic consequences for the future of the European Union. 